\title{
Sedimentologic, Heavy Mineral and Provenance Studies of the Cretaceous Sediments in the Auchi Area of the Anambra Basin
}

\section{ILEGIEUNO, OA; *IGHODARO, EJ; SUNNY, RO}

\author{
Department of Geology and Petroleum Studies, Western Delta University, Oghara, Delta State, Nigeria. \\ *Corresponding Author Email: ehikacross@gmail.com; Tel: +2348038598495
}

\begin{abstract}
The Upper Cretaceous Deposits of the Anambra Basin has a part of its sedimentary rock deposited in the Auchi area of Edo State. Geologic field and Sedimentological studies carried out on twenty eight (28) selected samples from a section of a road-cut show that the sediments range from fine through medium to coarse grained. Morphoscopic studies reveal subangular to subrounded outline of sand particles. These coupled with the various colours observed in the sediment, ranging from whitish sand through yellowish brown, pink and reddish brown possibly indicate a non-marine environment and a fluviatile to deltaic environment of sedimentation is suggested. Heavy mineral assemblage made up mainly of opaque, andalusite, zircon, hornblend, sphene and epidote sugges derivation from the Precambrian Igneous and medium to high grade metamorphic rocks of the underlying Basement Complex of Nigeria.
\end{abstract}

\section{DOI: https://dx.doi.org/10.4314/jasem.v24i6.1}

Copyright: Copyright (C) 2020 Ilegieuno et al. This is an open access article distributed under the Creative Commons Attribution License (CCL), which permits unrestricted use, distribution, and reproduction in any medium, provided the original work is properly cited.

Dates: Received: 09 April 2020; Revised: 17 May 2020; Accepted: 30 May 2020

Keywords: Sedimentology, Cretaceous, Morphoscopic, Heavy Mineral, Provenance

The sedimentary rock in Auchi area form parts of the Upper Cretaceous sediments of the Anambra Basin. The sedimentary rock in the basin, which continues into the West of the Niger, underlies a considered stretch of country, covering the entire land area of Agenebode, Fugar, Okpekpe, Uzairue and Auchi further west, Reyment (1965).

It is bounded to the north by the Crystalline Basement Complex of Nigeria (G. S. N. 1:100,000 series, Auchi sheet 266). Geologic observation reveals that the rock unit which is about $20 \mathrm{~m}$ thick at the representative section consist dominantly of partially indurated sandstone with occasional occurrence of sandy - clay at intervals. The top of the unit is capped by reddish brown sandy - clay at intervals. The top of the unit is capped by reddish - brown, sandy - clay intermixed with ferruginized sandstone and laterite soil.

This study aims at determining the provenance of the sediments via heavy mineral analysis.

\section{MATERIALS AND METHODS}

Study Area: The area under study is situated along Auchi - Igarra road in Etsako Local Government Area of Edo State. The area lies within latitude $6^{0} 10^{\prime} \mathrm{E}$ and $6^{0} 20^{\prime} \mathrm{E}$ and between longitude $7^{0} \mathrm{~N}$ and $7^{0} 10^{\prime} \mathrm{N}$ respectively.

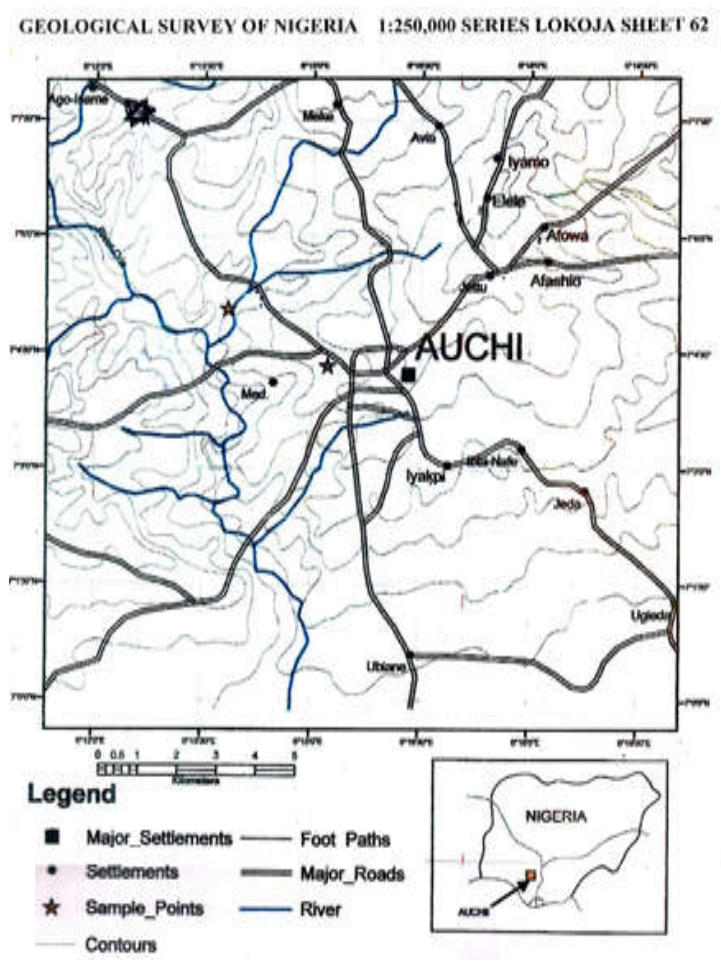

Fig. 1: Map of Auchi and environs showing Location of Study

Cretaceous Stratigraphy and Paleogeography of Southern Nigeria: The Cretaceous sedimentary rocks 
of Auchi area form a part that have accumulated in a variety of facies and thicknesses. According to Adeleye (1975), they cover about one-fourth of the land surface area of Nigeria. The depositional history started in the late Mesozoic time following the separation of the African and South - American continental landmass (Wright, 1975). Reconstruction of the Cretaceous sequence has been attempted by several workers among whom are: Adegoke (1969, 1978); Reyment (1965), Murat (1972); Adeleye (1975) and the Peters (1972). Based on stratigraphic evidence, the general concensus among workers is that basement subsidence, accompanied by normal marine transgression began in West Africa during Albian times. Deposition in southern Nigeria was first restricted to the eastern half of the Mesozoic Cenozoic coastal basins but later extended to other parts of Maastrichtian (Adegoke, 1969).

Table 1: Cretaceous Sequence in Southern Nigeria

\begin{tabular}{|c|c|c|}
\hline Age & $\begin{array}{l}\text { Western } \\
\text { Nigeria }\end{array}$ & Eastern Nigeria \\
\hline $\begin{array}{l}\text { Paleocene } \\
\text { Danian } \\
\text { Maastrichtian }\end{array}$ & $\begin{array}{l}\text { Abeokuta } \\
\text { Formation }\end{array}$ & $\begin{array}{l}\text { Nsukka Formation } \\
\text { Ajali Formation } \\
\text { Mamu Formation } \\
\text { Nkporo Formation } \\
\text { (Lateral equivalents } \\
\text { are Asata Shale, Enugu } \\
\text { Shale, Owerri } \\
\text { Sandstone) }\end{array}$ \\
\hline $\begin{array}{l}\text { Campanian - } \\
\text { Maastrichtian }\end{array}$ & & Agwu Formation \\
\hline $\begin{array}{l}\text { Conancian - } \\
\text { Santonian }\end{array}$ & $\begin{array}{l}\text { Basement } \\
\text { Complex }\end{array}$ & $\begin{array}{l}\text { Eze - Aku Formation } \\
\text { (Lateral equivalent } \\
\text { Amasiri Sandstone) }\end{array}$ \\
\hline Turonian & & Odukpani Formation \\
\hline Cenomanian & & $\begin{array}{l}\text { Unnamed Formation } \\
\text { (Unconformity) } \\
\text { Abakaliki Shale (Asu } \\
\text { River Group) } \\
\text { Basement Complex }\end{array}$ \\
\hline
\end{tabular}

The following methods were involved in this study: (a) Geological fieldwork and sample collection (b) Morphoscopic and Heavy Mineral Analysis:

Geological Fieldwork and Sample Collection: Lithologic Description of the Sandstone of Lokoja Formation within the Auchi - Igarra Area: The fieldwork was carried out to locate suitable outcrop sections and to determine the depth and thickness of the sections in the locality. Based on physical attributes such as colour, grain size and sorting, representative samples were taken from each distinct lithologic unit and were carefully described. The representative section is about $\mathrm{km} \mathrm{7,} \mathrm{along} \mathrm{Auchi} \mathrm{-}$ Igarra road and alongside River Orle $\mathrm{km} 4$ north of Auchi, The Bawa Hill outcrop along Auchi - Igarra road. It is $20 \mathrm{~m}$ thick and consists mainly of sandstone, sand and clay. These are distinguished or further subdivided on the basis of their physical attributes, which includes colour of sediments, sorting and grain - size.

1. Beginning from the bottom layer of the rock unit, the first $8 \mathrm{~m}$ intervals $(0-8.1 \mathrm{~m})$ consists of medium to coarse grained grits. The sediments are partly indurated - high and studded with quartz pebbles, which are angular to subangular with occasional subrounded outline. Some of the pebbles have diameters ranging between $4.00-4.50 \mathrm{~mm}$, a few horizons are found. The colour varies from white to pinkish brown but purplish variety are also present. It is cross bedded with large scale trough cross bedding. Towards the top, the section is iron - stained.

2. The second layer $(8.1-9.1 \mathrm{~m}$ thickness $)$ consist of sandy - clay which is about $1 \mathrm{~m}$ thick. It is brownish in colour, fine - medium grained sand and the grains are angular to sub-angular. Quartz constitute minerals present in this horizon.

3. The third layer $(9.1-13 \mathrm{~m}$ thick $)$ consists of highly consolidated sandstone, coarse grain and containing some quartz pebbles progressively becomes fine grained towards the top. Occasionally, thin bands (about $10 \mathrm{~cm}$ thick) of hard ferruginized sandstone occur. They appear conformable with the bedding, but they are, however, not continuous for a long distance. The grains are sub-angular - subrounded and moderately sorted. Colour is reddish brown. Both small and large scale trough cross bedding are present at the top. There are sometimes clayey - sand mixture within the layer.

4. The fourth layer $(13-15.9 \mathrm{~m})$ consist predominantly of clay which grades progressively upwards to sandy - clay. The clay horizon is typically grayish in colour and massive. The succeeding clay portion is fine to medium grained and highly compacted with clay cementation. The sand grains are sub-angular to sub-round. The colour varies from light brown to yellowish brown.

5. The fifth layer $(15.9-19.4 \mathrm{~m})$ represent the top most part of the sequence. It's about $3.5 \mathrm{~m}$ thick. It consists of highly ferruginised and indurated sandstone of about $1 \mathrm{~m}$ thick below and succeeded by a portion showing considerable leaching at the top. Grain size ranges from through medium to coarse grain. Sorting is poor and grains are sub-rounded to round.

In general, the layer consists of an alternating sequence of sandstone and sandy - clay with the sandstone portion predominating. Clay horizon are not common and where it persist, there is a gradual facie change in a lateral direction.

Sample analysis (Morphoscopic and Heavy Mineral Analysis): The sample analysis involved detailed 
analytical study of the samples collected in the field with a view to determine their geological characteristics. The laboratory work include: Morphoscopic determination and Heavy mineral analysis.

Morphoscopic Analysis: Morphoscopic analysis carried out on the sanples collected from the formation give an idea of the roundness and sphericity of the grain. The two parameters are not environmentally sensitive but depends on medium and mode of transportation as well as original form of the grains. Folk (1974), has shown that roundness is geometrically independent of sphericity, but still increases downstream. Since different particle size undergoes different degree of roundness, a sand size range was selected for examination. Hence all the grains will be assumed to be characterized by the same mode of transportation, that is, the difference observed will be related to the mode and length of transport.

About 100 grains were selected from each samples and examined under the Binocular Microscope as well as Hand Lens. Each grain is assigned to a particular class under a visual chart of Krumbrein and Sloss (1953) for estimating roundness and sphericity. The frequency of each grain were noted and the average value estimated.

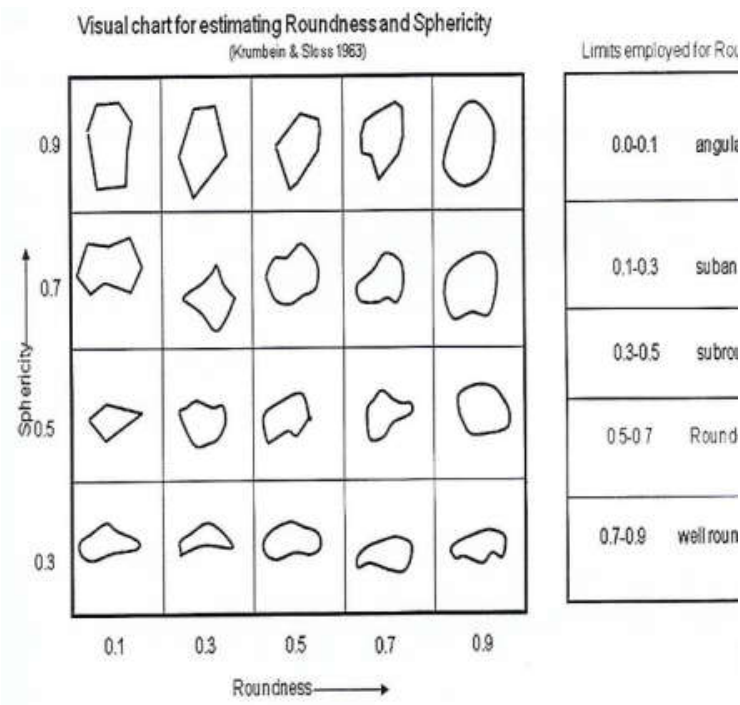

Fig 2: Virtual Chart for Estimating Roundness and Sphericity

Heavy Mineral Analysis: Twenty eight (28) samples were selected for heavy mineral analyses using the fraction retained in the 75 micro mesh sieve. The apparatus for heavy mineral analysis includes a separating funnel to hold the heavy liquid (Bromoform S.G. $=2.85$ ), a filtering funnel with filter papers, a collecting flat bottom flask and a retort stand. The separating flask/funnel was partly filled with Bromoform and the first sediment introduced into the separating flask containing the Bromoform. The mixture was then stored with a rod until the heavy fraction were no longer observed to sink to the bottom of the flask. The stopped was then opened gently to allow the accumulated heavy mineral flow out and be collected in the filter paper the filtering funnel. The heavy minerals (Bromoform) drains into the flat bottom flask under the filtering funnel. Thereafter, the flat bottom flask containing Bromoform was then removed and replaced with another flask. The heavy minerals obtained was then washed several times with methylated spirit and set aside to dry. After which heavy minerals were mounted on glass slides using Canada balsam and examined later for heavy mineral distribution under a petrographic microscope. Results of analysis were used in deciphering the provenance of the sediments

\section{RESULTS AND DISCUSSION}

Geological Fieldwork: Field studies of outcrop section on the Benin Flank have revealed Lower Cretaceous Sedimentary rocks in the Auchi - Igarra area reminiscent of those described as the Lokoja Bassange Formation of the Southern Bida by Jone (1958), Adeleye and Dessauvagie (1972), Idowu and Enu (1992). The same rock unit has been named as Lokoja Sandstone of the Southern Bida Basin by Jan du Chene et al (1978), Akande et al (2005). These rock types are similarly referred to in this work as Lokoja Bassange Formation as they are lateral equivalents due to similar features. They overlie the basement rocks unconformably in six geographical localities in the Auchi areas respectively.

Lithostratigraphic studies of the rock type shows that the section is composed dominantly of sandstone with occasional occurrence of sandy clay at intervals.

The sandstone and grits which occur mostly at the rock section are medium to coarse grain with pebble occurrence, pinkish colour and iron stained or ferriginous and generally it is moderately to poorly sort. The sandstone is frequently clay supported which make it looks dirty and this is characteristic of submature sandstone. Also, the sand grains are angular at the base with varieties of colour (ranging from brown, pink, and purplish to whitish grey) and this probably indicates rapid fluctuation between Lacustrine and Deltaic conditions (Picard, 1957). The presence of large scale Trough - cross beddings is indicative of fluvial environment, clay lines or intercalation in the sandstone beds may represent over bank flood deposit (Potter, 1967). 
Morphoscopic Analysis: Morphoscopic studies reveals that majority of the samples analysed are within the range of angular to sub-angular. Similarly, the estimated sphericity value falls within an average range of moderate to low. A careful observation of the overall samples show that a large proportion of the grain has almost the same roundness. It was also observed that the surface of the grains are smooth indicating that they have not undergone much breakage. Although the coarse nature of the sediments (as obtained from grain - size distribution) implies deposition in a slightly stable high energy environment, Pettijohn (1974). It can be said from the absence of breakage that the occasional high velocity current which could cause considerable breakage during transportation, a similar example was cited Krumbein (1941). Nevertheless, roundness study alone cannot be said to provide direct clues to depositional environment.

The value of roundness (range of limit) employed were: Angular $=0.0-0.15$; Subangualr: $=0.15-0.25$; Subrounded: $=0.25-0.40$; Rounded $=0.40-0.75$; Well Rounded; $0.75-1.0$

Table 2: Roundness and Sphericity Values

\begin{tabular}{llll}
\hline S/N & No. & Shape/Roundness & Sphericity Value \\
\hline 1 & 1 & Angular - Subangular & Low \\
2 & 2 & Angular - Subangular & Low \\
3 & 3 & Angular - Subangular & Low \\
4 & 5 & Subangular - Subrounded & Moderate \\
5 & 6 & Subangular - Subrounded & Moderate \\
6 & 7 & Subangular - Subrounded & Moderate \\
7 & 9 & Subangular - Subrounded & Moderate \\
8 & 10 & Angular - Subangular & Low \\
9 & 12 & Angular - Subangular & Low \\
10 & 15 & Angular-Subangular & Low \\
11 & 19 & Angular-Subangular & Low \\
12 & 21 & Subangular - Subrounded & Moderate \\
13 & 22 & Subangular - Subrounded & Moderate \\
14 & 23 & Subrounded - Rounded & High \\
15 & 24 & Angular - Subangular & Low \\
16 & 25 & Angular-Subangular & Moderate \\
17 & 26 & Subangular - Subrounded & Moderate \\
18 & 27 & Subangular - Subrounded & Moderate \\
19 & 28 & Subangular - Subrounded & Moderate \\
20 & 29 & Subangular - Subrounded & Moderate \\
21 & 30 & Subrounded - Rounded & High \\
22 & 31 & Subrounded - Rounded & High \\
23 & 32 & Subangular - Subrounded & Moderate \\
\hline & & &
\end{tabular}

Provenance: The provenance of the sediments was based on heavy minerals recovered from the sediments. Heavy minerals identified in the sediments include zircon, rutile, sphere, hornblende and tourmaline. Tourmaline is a metamorphic mineral, hence indicate a metamorphic source for the sediment; while zircon, rutile, sphere and hornblende are igneous minerals and this indicate an igneous source of the sediment. Therefore, the sediments could have been said to be derived from the weathering of igneous and metamorphic rock of the adjourning crystalline basement complex.

Conclusion: From the foregoing, one can conclusively say that the sediments were derived from igneous and metamorphic rock, not too far from the area of deposition, and also pre - existing sediments. The subangular to sub-rounded nature of the grains with little amount of angular grains possibly indicates that the sediments have moved fairly short distance from the source material and have also been derived from re working of pre - existing sediments. The heavy mineral assemblage suggest derivation from Igneous and metamorphic rock of the adjoining Basement Complex, and the above evidence suggests a non marine environment of deposition.

\section{REFERENCES}

Adegoke, OS (1969). Eocene Stratigraphy of Southern Nigeria-Memoires du B.R.G.M. No. P. 69

Adegoke, OS. (1978). Ancient Seaways, Sediments and their Recorded History: Inaugural Lecture, Series $31, . \mathrm{p} 43$

Adeleye, DR. (1975). Nigeria Late Cretaceous Stratigraphy and Paleogeography. Am. Assoc. Petroleum Geol. Bull. 59: 2303 - 2313.

Adeleye, DR. and Dessauvagie, T.F.J. (1972): Stratigraphy of the Niger Embayment, Near Bida Basin, Nigeria. In T.F.J. Dessauvagie and A.J. Whiteman (eds) African Geology, University of Ibadan. University of Ibadan Press. 181 - 186pp.

Akande, S. O., Ojo, O. J., Erdtmann, BD and Hetenyi, M. (2005): Paleo - Organic Petro and Rock - Eval Studies on Source Rock Facies of the Lower. Pp $20-35$

Folk, RK. (1951). Stages of Textural Maturity in Sedimentary Rocks. J. Sediment. Rocks. 2 (3) 127 -130 .

Folk, RL. (1974). Petrology of Sedimentary Rock. Hemphille's Austin, Texas, Pp 182.

Idowu, J. O. and Enu, E. I. (1992): Petroleum Geochemistry of some Late Cretaceous Shales from the Lokoja Sandstone of Middle Niger Basin. Journ. Of African Earth Sciences, Vol. 14, $443-455 p p$. 
Jan Du Chene, R. E., Perch - Nielson, K. and Petters, S. W. (1978): New Stratigraphic Data on the Paleogene Ewekoro and Akinbo Formations, South Western Nigeria. Archives Des Sciences, Vol. 31; $205-212$ pp.

Jones, H. A. (1958): The Oolitic Ironstone of Agbaja Plateau, Kabba Province. Records of the Geological Survey of Nigeria, 20-43pp.

Krumbein, NC. (1941). Measurement and Geologic Significance of Shape and Roundness of Rock Fragments. J. Sediment. Petrol. 11:464-572.

Krumbein, N. C., and Sloss, L.L. (1963): Stratigraphy and Sedimentation W. H. Freeman and Company. San Francisco \& London ( $2^{\text {nd }}$ ed.)

Murat, RC. (1972). Stratigraphy and Paleogeography of the Cretaceous and Lower Tertiary in Southern Nigeria. In Dessauvagie, T.F.J. and Whiteman, A.J. eds. African Geology, 251 - 266.
Pettijohn, P.J. (1975). Sedimentary Rock. Harper \& Row, N.Y., Pp 628 ( $3^{\text {rd }}$ ed.)

Potter, P. E. (1967). Sand Bodies and Sedimentary Environments: A Review. Bull. Am. Assoc. Petroleum Geol. 51: 337 - 365

Powers (1953). A New Roundness Scale for Sedimentary Particles. J. Sediment. Petrol. 23: $117-119$.

Reyment, R. A. (1965). Aspect of Geology of Nigeria. Ibadan University Press

Wright, J. B. (975). Origin of the Benue Trough $-A$ Critical Review (In) Geology of Nigeria (Ed. Kogbe, C. A.) P. $309-317$. 